\title{
Energetic metabolic profile of ewes presenting low body condition score induced to subclinical hypocalcemia in early postpartum
}

\author{
Eduardo Schmitt ${ }^{\mathrm{a}}$, Andressa S. Maffi ${ }^{\mathrm{a}}$, Raquel F. S. Raimondo ${ }^{\mathrm{a}, \mathrm{b}}$, Marcio E. Lima ${ }^{\mathrm{a}}$, \\ Dustin A. C. Hoffmanna, Tiago S. Farofaa, Paula Montagnera, Joao A. A. Rincón ${ }^{a}$, \\ Francisco A. B. Del Pino a , Marcio N. Corrêa ${ }^{a}$
}

\begin{abstract}
The aim of the present study is to assess plasma concentrations of metabolites related to energy balance in ewes showing low body condition score (BCS) induced to subclinical hypocalcemia in early postpartum. Sixteen crossbred ewes (Ideal $\mathrm{x}$ Corriedale) presenting BCS $<3$ were divided in two groups: 1) control group ( $\mathrm{n}=9)$, which received no treatment, and 2) hypocalcemia group $(n=7)$, which was subjected to twelve hours of induced subclinical hypocalcemia through intravenous $\mathrm{Na}_{2}$ EDTA infusion six hours postpartum. Ionized calcium levels were monitored and kept between 0.62 and $0.87 \mathrm{mmol} / \mathrm{L}$. All ewes were subjected to daily blood sampling for five days in order to set the postpartum metabolic profile. There was no interaction between day and treatment in total and ionized calcium concentrations $(P>0.05)$, whereas the mean concentrations of these marks after five days were lower in the hypocalcemia group $(P<0.05)$. However, neither the mean group were different at glucose, non-esterified fatty acids, beta-hydroxybutyrate and insulin $(P>0.05)$ level. These results evidence that, despite the subclinical hypocalcemia induction at early postpartum, ewes presenting low body condition do not change the concentrations of energy balance-related metabolites in the following five days.

Key words: subclinical hypocalcemia, metabolic profile, calcemia, low body condition, sheep.
\end{abstract}

\section{INTRODUCTION}

The late gestation period in sheep is critical, since it demands greater nutritional needs and nutrient availability to udder development and body maintenance (El-sherif and Assad 2001). Pregnant and lactating ewes redirect most glucose and amino acid supplies to the fetal-placental unit and mammary gland throughout this period, since such transfer largely accounts for the high energy requirement (Chilliard 1999). Late gestation and early lactation coincide with a period of low native forage availability in the extensive pasture systems of Southern Brazil (Ribeiro et al 2004, Carvalho and Bartello 2009). The low temperatures and high animal stocking per hectare set high metabolic challenges to pregnant ewes, because such factors lead to low energy intake during high-demand periods.

These events, cause gluconeogenesis substrate reduction and lead to hypoglycemia. The decrease of glucose level fosters increased lipolysis rates, as well as the release of fat, triglycerides and NEFA (Harmeyer and Schulunbhon 2006). Such low supply and high nutritional demand increase the risk of developing metabolic diseases. Pregnant and lactating ewes can develop ketosis, which is usually responsible for significant losses in production systems, depending on NEFA mobilization intensity, and the production and metabolization ability of ketone bodies

Accepted: 02.11.2017.

aUniversidade Federal de Pelotas (UFPel), Departamento de Clinicas Veterinária, Núcleo de Pesquisa, Ensino e Extensão em Pecuária (NUPEEC), Rio Grande do Sul, Brazil.

${ }^{\text {b}}$ Universidade Federal do Rio Grande do Sul (UFRGS), Faculdade de Veterinária, Departamento de Medicina Animal, Rio Grande do Sul, Brazil.

Corresponding author: E Schmitt; schmitt.edu@gmail.com
(Henze et al 1998). Negative energy balance intensity also depends on the ability of tissues and their time to adapt to different metabolic pathways adopted for energy production (Chilliard et al 2000, Loor et al 2006). Smith and Sherman (1994) suggest that ewes must keep a body condition score (BCS) between 3.0 and 3.5 in the final third of pregnancy, 3.5 at birth, and between 2.0 and 2.5 at weaning in order to achieve energy balance.

Besides ketosis, hypocalcemia also contributes to higher production losses and ewe mortality rates during peripartum (Mavrogianni and Brozos 2008). Unlike hypocalcemia in cows, which often happens in postpartum, when it comes to sheep the disease develops from several weeks before birth until the first two weeks after birth. Approximately $60 \%$ of the fetal growth takes place in the final gestation period (Twardock et al 1973), when the fetus retains higher calcium levels for skeletal growth, providing a negative late pregnancy calcium balance in most sheep (Braithwaite et al 1970), which is characterised by total calcium blood levels below $2.0 \mathrm{mmol} / \mathrm{L}$ (Oetzel 2004, El-Khodery et al 2008). Studies have shown that approximately $50 \%$ of pregnant ewes present total calcium concentration in blood plasma below the reference value for late pregnancy, whereas healthy non-pregnant ewes show total $\mathrm{Ca}$ plasma concentration close to $1.25 \mathrm{mmol} / \mathrm{L}$ (Henze et al 1994).

Endogenous glucose production can be compromised during negative energy balance periods, when the excess of ketone bodies are associated with low calcium levels (Schlumbohm and Harmeyer 2003). Furthermore, clinical hypocalcemia can also reduce insulin secretion caused by calcium participation in the insulin exocytosis process in pancreatic $\beta$ cells (Rutter et al 2006), despite the high plasmatic glucose levels (Blum et al 1972, Henze et al 1998). 
Based on these evidences, this study hypothesizes that ewes with low body condition at lambing which are submitted to subclinical hypocalcemia in the postpartum period have greater negative energy balance. The aim of the current study was to assess the effect from induced subclinical hypocalcemia on the energetic metabolic profile of ewes presenting low body condition score during the five first lactation days.

\section{MATERIAL AND METHODS}

The Ethics Committee on Animal Experimentation of the Federal University of Pelotas approved all the procedures carried out during the experiment.

The experiment was conducted at the Sheep Experiment Department of NUPEEC - Núcleo de Pesquisa, Ensino e Extensão em Pecuária (Livestock Research, Teaching and Extension Center) of the Federal University of Pelotas, Rio Grande do Sul State, Brazil (31 ${ }^{\circ} 48$ ' $58^{\text {"S" }}$ " and $52^{\circ}$ $25,55 \mathrm{~W})$. Sixteen crossbred ewes (Ideal x Corriedale) averaging 3.5 years of age, between the 110th and 140th gestation day, showing body condition score (BCS) lower than 3 (range 1-5) were used (Russel et al 1969). During daytime, ewes were kept for six hours in 2-hectare pasture area containing ray grass (Lolium multiflorum) and oat (Avena strigosa). The pasture area was divided in alternated paddocks, according to forage availability to minimize eventual nutritional management effects. The estimated total forage availability during the experimental period was $1,100 \mathrm{~kg}$ dry matter per hectare. Samples were collected for pasture bromatological analysis through the manual simulated-grazing method. The recorded means were $20.2 \%$, for crude protein; $25 \%$, for acid detergent fiber (ADF); and $60.5 \%$, for neutral detergent fiber (NDF).

Sheep at the lambing were randomly divided in two groups: 1) control $(n=9)$, and 2) hypocalcemia $(n=7)$. Group 2 (hypocalcemia) consisted of sheep subjected to twelve hours of induced subclinical hypocalcemia six hours after lambing. Each ewe gave birth to a single lamb. Mean lamb body weight was not different between groups $(3.1 \pm 0.7$ vs $4 \pm 0.4 \mathrm{Kg} / \mathrm{BW}$ for the control and hypocalcemia groups, respectively). Subclinical hypocalcemia induction was conducted by administrating $5 \% \mathrm{Na}_{2}$ EDTA ( $\mathrm{pH} 7.35$ 7.45 ) through intravenous catheter at rate 10 drops/minute, according to Jørgensen et al (1999). The administration rate depended on the ionized calcium plasma level, which was measured every one hour in order to be kept between 0.62 and $0.87 \mathrm{mmol} / \mathrm{L}$. The $5 \mathrm{~mL}$ blood aliquot was directly collected from the catheter with the aid of a heparinized syringe ( $2 \%$ heparin) aiming at monitoring the ionized calcium. The samples were analysed in the Orion 290A + pH pH advanced ISE7MVT (Thermo Fisher Scientific, USA) meter adapted with a selective electrode for calcium ions. Sheep were kept with their offspring to prevent further stress throughout the induction period.
Blood samples were collected in a daily basis for five postpartum days. The first collection (day 1) was performed 12 hours after lambing. Blood samples were collected through jugular vein puncture according to the Vacutainer system (BD Diagnosis, Sao Paulo, Brazil) by using two previously identified tubes. One tube contained anticoagulant (10\% EDTA) and antiglicolytics (12\% KF Potassium fluoride) for glucose analysis. The other one did not have anticoagulant and was used for calcium, magnesium, phosphorus, chloride, albumin, insulin, NEFA and $\beta$-hydroxybutyrate analysis. Blood samples were centrifuged right after collection to obtain serum or plasma, which were placed in microtubes and frozen for further analysis.

Calcium, magnesium, phosphorus, chloride, glucose and albumin levels were evaluated from the first day until the fifth day after subclinical hypocalcemia induction, and were analysed by colorimetric enzymatic kits (Labtest Diagnostica SA, Brazil), according to the instructions of the manufacturer, in the UV/visible spectrophotometer (FEMTO 435, FEMTO Industry and Trade Instruments, São Paulo, Brazil).

Insulin levels were evaluated from the first to the third day after induction subclinical hypocalcemia. The analysis was performed using a kit DSL-10-1600 ACTIVE Insulin sandwich immunoassay kit (Diagnostics Systems Laboratories Inc., Webster, TX, USA), according to the method described by Lee et al (2002). Readings were conducted in plate reader (Thermo Plate TP-Reader, São Paulo, Brazil).

The NEFA levels were evaluated from the first to the fifth day after subclinical hypocalcemia induction, the analysis was performed by using the RH Series NEFA kit (WakeChemicals, USA); the $\beta$-hydroxybutyrate analysis was conducted with the Ranbut commercial kit (Randox Laboratories, Oceanside, CA, USA). Both analyses followed the method described by Ballou et al (2009).

\section{STATISTICAL ANALYSIS}

Statistical analysis was performed by SAS statistical software (SAS Institute Inc., Cary, NC, USA), version 9.0. Results were presented as mean and standard error of the mean; data were analysed by through ANOVA with repeated measurements; collection time was the repetitions, sheep were the experimental units, animals within their respective groups were the random effect, and the groups were the fixed effect. Blood levels of the analysed metabolites were included as dependent variables. Means were compared through Tukey-Kramer test. Statistical differences were defined as $P \leq 0.05$.

\section{RESULTS}

Figure 1 shows that hypocalcemia was successfully induced, since the calcium concentration was kept in rates 


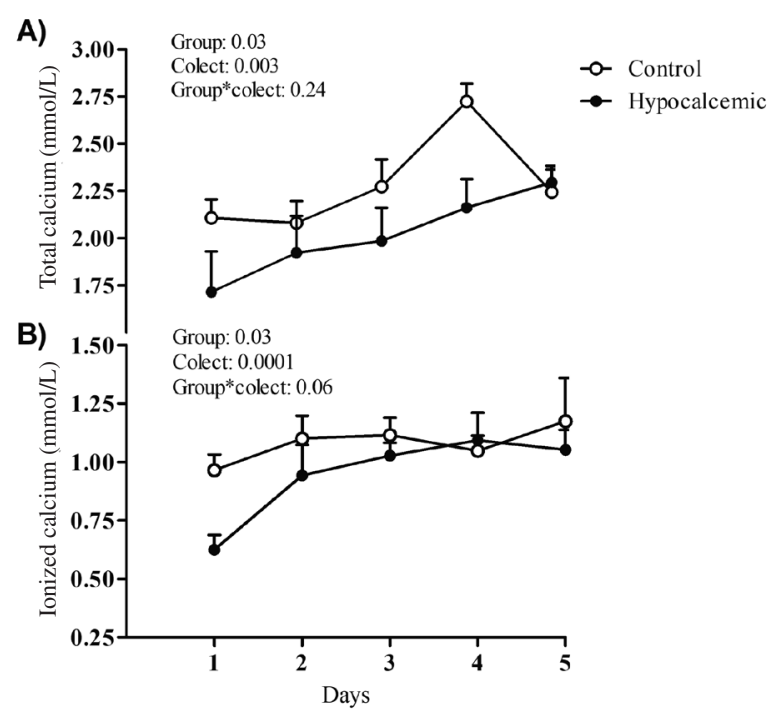

Figure 1. Total (A) and ionized calcium (B) levels (in serum and plasma, respectively) in the control $(O, n=9)$ and hypocalcemic $(\bullet, n=7)$ groups during the 5-day postpartum period.

lower than $2 \mathrm{mmol} / \mathrm{L}$ of total calcium and between 0.62 and $1 \mathrm{mmol} / \mathrm{L}$ of ionized calcium in the hypocalcemia group from day one. Apparently, the ionized calcium levels did not influence just induction day when their means were $0.96 \pm 0.07 \mathrm{mmol} / \mathrm{L}$ and $0.62 \pm 0.06 \mathrm{mmol} / \mathrm{L}$, in the control and hypocalcemic groups, respectively. Mean ionized calcium was different between the control and hypocalcemic groups $(P=0.03)$ during the 5-day period $(1.10 \pm 0.04$ and $0.97 \pm 0.04 \mathrm{mmol} / \mathrm{L}$, respectively). The same was observed for total calcium (figure 1) level during this period, the recorded means were $2.29 \pm 0.06$ and $2.01 \pm 0.07 \mathrm{mmol} / \mathrm{L}$ for the control and hypocalcemic groups, respectively $(P=0.03)$. Induced-hypocalcemia ewes maintained total calcium levels below $2.1 \mathrm{mmol} / \mathrm{L}$ in the first three postpartum days. The levels of energetic metabolics (figure 2) were not affected $(P>0.05)$, despite the occurrence of subclinical hypocalcemia. The mean NEFA concentration recorded for the control group was $0.98 \pm 0.17 \mathrm{mmol} / \mathrm{L}$, and $1.00 \pm 0.15 \mathrm{mmol} / \mathrm{L}(P=0.85)$ for the hypocalcemia group. The mean BHBA concentration for the control group was $0.83 \pm 0.23 \mathrm{mmol} / \mathrm{L}$, and $0.71 \pm 0.16$ $\mathrm{mmol} / \mathrm{L}(P=0.55)$ for the hypocalcemia group. Glucose was within the physiological level (figure 2) during the early lactation period, with values of $2.99 \pm 0.22 \mathrm{mmol} / \mathrm{L}$ and $2.91 \pm 0.20 \mathrm{mmol} / \mathrm{L}$, in control and hypocalcemic groups, respectively $(P=0.96)$. The concentration of this metabolic was different between collections only, the highest concentrations were observed at the first postpartum day. The mean insulin concentration recorded for the control group was $4.81 \pm 0.45 \mu \mathrm{UI} / \mathrm{mL}$, and $3.15 \pm 0.62 \mu \mathrm{UI} / \mathrm{mL}(P=0.06)$ for the hypocalcemia group.

Apparently, subclinical hypocalcemia induction influenced the phosphorus levels $(P=0.002)$ and led to higher serum levels in hypocalcemic ewes after five days (hypocalcemic group $1.74 \pm 0.12 \mathrm{mmol} / \mathrm{L}$; control group $1.39 \pm 0.08$ $\mathrm{mmol} / \mathrm{L}$ ) (table 1), thus showing greater amplitude at the
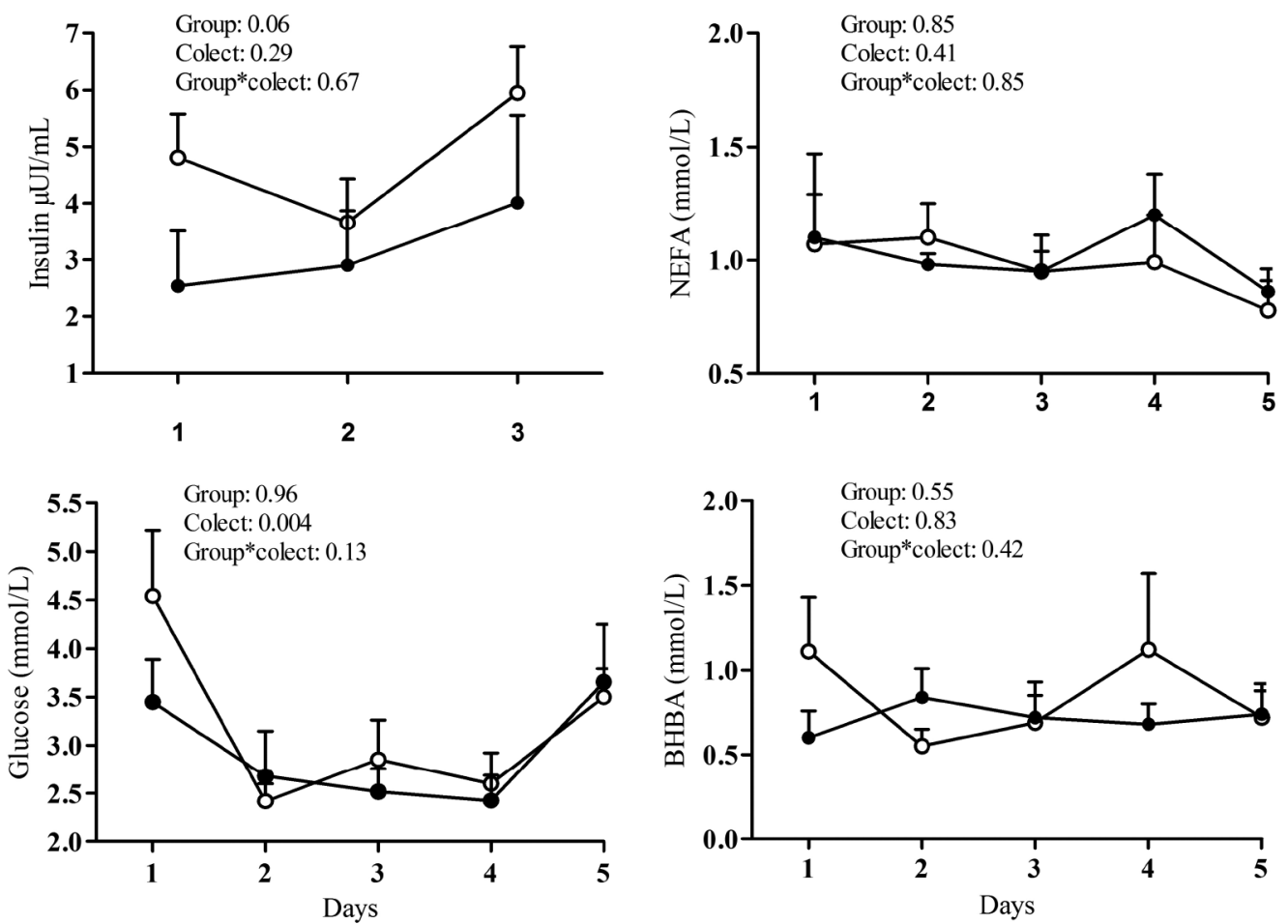

Figure 2. Insulin, $(\mu \mathrm{UI} / \mathrm{ml})$, non-esterified fatty acids ( $\mathrm{mmol} / \mathrm{L})$, glucose $(\mathrm{mmol} / \mathrm{L})$ and $\beta$-hydroxybutyrate $(\mathrm{mmol} / \mathrm{L})$ levels in the 5 -day postpartum period for the control $(O, n=9)$ and hypocalcemic $(\bullet, n=7)$ groups. 
first day. The concentration levels of albumin, magnesium and chloride in the serum were not affected by subclinical hypocalcemia (table $1, P>0.05$ ).

\section{DISCUSSION}

Figure 1 showed that subclinic hypocalcemia induced at the first postpartum day can disrupt calcium metabolism in the following days. Although renal excretion of the CaEDTA complex is completed few hours after $\mathrm{Na}_{2}$ EDTA infusion (Aronson and Ahrens 1971), in some cases hypocalcemia is induced with $\mathrm{Na}_{2}$ EDTA, and it leads to lower gastrointestinal tract motility. Such low motility impairs the animals' recovery ability, because the calcium absorbed by the intestine is essential to the maintenance of the calcium level itself (Jørgensen et al 1999). Thus, calcium level recovery in ewes subjected to subclinical hypocalcemia induction would happen slowly. This recovery process can be followed by lower dry matter intake due to decreased gastrointestinal motility (Goff 2006). However, the induced subclinical hypocalcemia did not influence energy balance in the present study (figure 2). The NEFA level in both groups was consistent with the catabolism state (Caldeira 2005). Fırat and Özpınar (2002) measured the NEFA level in ewes with adequate body condition and reported levels varying from 0.64 to $0.68 \mathrm{mmol} / \mathrm{L}$ at the 100 th gestation day and at the 10th lactation day, respectively. However, Cal-Pereyra et al (2015) observed NEFA level $1.28 \mathrm{mmol} / \mathrm{L}$ in ewes restricted to the last gestation, whereas sheep without restrictions presented values close to $0.18 \mathrm{mmol} / \mathrm{L}$. Food restriction also led to glucose level reduction right after the beginning of the restriction period in the study by Cal-Pereyra et al (2015). However, significant differences in glucose levels were observed only from the 54th hour on, between animals with and without restrictions, and the physiological level returned during the 102nd hour after. In addition, glucose level reduction was followed by NEFA and BHBA increase in the circulatory starting from the 48th hour of the restriction periods. Such levels remained high up to the 144th hour, and the animals were not monitored after this period.

Despite the low body condition at lambing and the high NEFA levels in the current study, the mean BHBA levels remained within the baseline limits for the period (Durak 2006, Harmeyer and Schlumbohm 2006). Ewes seem to have optimized the use of ketone bodies by peripheral tissues in order to supply energy during the pre-partum period. It may be the consequence from a strategy developed to adapt to low volatile fatty acids and glucose availability (Caldeira 2005). The same condition was also observed during postpartum, regardless of the group. Although some sheep showed ketone body peaks, such peaks did not meet the hypocalcemia period, therefore, it may have contributed to the absence of effects on glucose metabolism. Glucose was within the physiological level throughout the early lactation period (Caldeira 2005, Roubies et al 2006). The highest concentrations were observed at the first postpartum day, and it can be attributed to cortisol actions. This hormone gradually increases five days before delivery, and allows greater circulating glucose availability; thus, it influences the action of glucose carrier GLUT4 in peripheral tissues, as well as stimulates hepatic gluconeogenesis (Bassett 1963, Fowden 1997, Ingvartsen and Andersen 2000). The results contradict the reports of Schlumbohm and Harmeyer (2003), who showed the hindering effect of hypocalcemia on glucose turnover. However, the study by Schlumbohm and Harmeyer (2003) proved that ewes were in good body condition before the beginning of the experiment. These authors evaluated sheep in different production stages and suggested a sequence of events that take place in the body of hyperketonic and hypocalcemic sheep, namely: decreased endogenous glucose and restricted glucose availability, lipolysis rate stimulation, and increased BHBA rate with consequent glucose depression intensification. Such effect was not observed in cases in which the calcium rate dropped down without parallel BHBA increase. Subclinical hypocalcemia may have significant depressor effect on carbohydrate metabolism

Table 1. Some metabolic parameters of the hypocalcemic and control groups in 5-day postpartum period (mean + standard deviation).

\begin{tabular}{|c|c|c|c|c|c|c|c|c|c|c|c|c|c|}
\hline \multirow{3}{*}{ Variable } & \multicolumn{10}{|c|}{ Postpartum days } & \multirow{2}{*}{\multicolumn{3}{|c|}{ Value P }} \\
\hline & \multicolumn{5}{|c|}{ Control } & \multicolumn{5}{|c|}{ Hypocalcemic } & & & \\
\hline & 1 & 2 & 3 & 4 & 5 & 1 & 2 & 3 & 4 & 5 & Group & Colect & $\begin{array}{l}\text { Group* } \\
\text { Colect }\end{array}$ \\
\hline $\begin{array}{l}\text { Phosphorous } \\
(\mathrm{mmol} / \mathrm{L})^{*}\end{array}$ & $1.40 \pm 0.14$ & $1.39 \pm 0.26$ & $1.58 \pm 0.18$ & $1.33 \pm 0.23$ & $1.27 \pm 0.07$ & $2.02 \pm 0.35$ & $1.50 \pm 0.26$ & $1.49 \pm 0.0 .19$ & $1.78 \pm 0.20$ & $1.87 \pm 0.27$ & 0,002 & 0,89 & 0,46 \\
\hline $\begin{array}{l}\text { Magnesium } \\
(\mathrm{mmol} / \mathrm{L})\end{array}$ & $0.94 \pm 0.11$ & $0.89 \pm 0.12$ & $0.93 \pm 0.08$ & $0.68 \pm 0.07$ & $0.67 \pm 0.15$ & $1.01 \pm 0.16$ & $1.05 \pm 0.43$ & $1.03 \pm 0.26$ & $0.72 \pm 0.07$ & $1.18 \pm 0.32$ & 0,14 & 0,45 & 0,71 \\
\hline $\begin{array}{l}\text { Chlorides } \\
(\mathrm{mmol} / \mathrm{L})\end{array}$ & $106.81 \pm 2.84$ & $110.30 \pm 5.74$ & $104.65 \pm 4.18$ & $102.76 \pm 2.51$ & $103.73 \pm 2.49$ & $111.05 \pm 4.85$ & $110.27 \pm 3.69$ & $115.51 \pm 4.53$ & $108.57 \pm 4.30$ & $107.36 \pm 4.77$ & 0,29 & 0,50 & 0,46 \\
\hline Albumin $(\mathrm{g} / \mathrm{L})$ & $28.75 \pm 0.76$ & $29.10 \pm 1.19$ & $28.57 \pm 1.06$ & $27.19 \pm 1.06$ & $27.77 \pm 1.09$ & $30.16 \pm 3.17$ & $28.72 \pm 1.72$ & $30.13 \pm 1.90$ & $28.88 \pm 1.29$ & $28.68 \pm 1.23$ & 0,39 & 0,74 & 0,94 \\
\hline
\end{tabular}

* Variables with the means from all the experimental period differed between groups $(P<0.05)$. 
when ewes are not adapted to energy deficit and to high levels of ketone bodies. Insulin concentrations were not influenced by hypocalcemia, although studies in dairy cattle already showed that low calcium concentrations can decrease the secretion of this hormone (Blum et al 1972); this effect seems to be restricted to clinical hypocalcemia (total calcium $<1.25 \mathrm{mmol} / \mathrm{L}$ ).

Serum albumin was within the reference range for the species in both groups, when protein metabolism was assessed (Balikci et al 2007). However, due to the low synthesis and degradation rates of this protein, longer deficiency periods (approximately one month) are necessary, so that blood concentrations could drop down (Contreras et al 2000). Seemingly, subclinical hypocalcemia induction influenced the phosphorus levels and led to higher serum levels in hypocalcemic ewes at the end of five days, thus showing greater amplitude at the first day. This outcome may have resulted from the phosphorus release from bone tissue and mediated by the PTH action, in order to increase calcium levels. Although this hormone also increases phosphorus excretion in the proximal convoluted tubule, the presence of calcium in the tubule lumen is a mechanism used to stimulate phosphorus absorption, which may be a decisive factor for hypocalcemia induction (Bisello and Fiedman 2008). Magnesium and chloride levels were not affected by subclinical hypocalcemia (table 1).

Although subclinical hypocalcemia may be identified as a disease contributing to negative energy balance in the postpartum of ruminants (Goff 2006, Schlumbohm and Harmeyer 2003), the herein recorded metabolic profile suggested that these effects were not observed in ewes presenting low body condition at lambing. Therefore, it suggests that animals adapt to this condition, and that such adaptation is mainly based on glucose, NEFA and ketone body availability and supply (Herdt 2000).

Based on results, which were in opposition to the hypothesis addressed in the present study, it is possible to conclude that subclinical hypocalcemia induction during early postpartum does not change the concentrations of metabolites related to energy balance of ewes presenting low body condition during the first five lactation days.

\section{ACKNOWLEDGEMENTS}

The authors would like to thank CAPES - Coordination for the Improvement of Higher Education Personnel - for their financial support.

\section{REFERENCES}

Aronson AL, Ahrens FA. 1971. The mechanism of renal transport and excretion of ethylenediaminetetraacetate with interspecies comparisons. Toxicol Appl Pharm 18, 1-9.

Balikci E, Yildiz A, Gürdoğan F. 2007. Blood metabolite concentrations during pregnancy and postpartum in Akkaraman ewes. Small Ruminant Res 67, 247-251.

Ballou MA, Gomes RC, Juchem O, DePeters EJ. 2009. Effects of dietary supplemental fish oil during the peripartum period on blood metabolites and hepatic fatty acid compositions and total triacylglycerol concentrations of multiparous Holstein cows. J Dairy Sci 92, 657-669.
Bassett JM. 1963. The influence of cortisol on food intake and glucose metabolism in sheep. $J$ Endocrinol 26, 539-553.

Bisello A, Friedman PA. 2008. PTH and PTHrP actions on kidney and bone. In: Bilezikian JP, Raiz LG, Martin TJ (eds). Principles of Bone Biology. Elsevier, San Diego, California, USA, Pp 665-712.

Blum JW, Wilson RB, Kronfeld DS. 1972. Plasma insulin concentrations in parturient cows. J Dairy Sci 56, 459-464.

Braithwaite GD, Glascock RF, Riazuddin S. 1970. Calcium metabolism in pregnant ewes. Br J Nutr 24, 661-670.

Caldeira RM. 2005. Monitorização da adequação do plano alimentar e do estado nutricional em ovelhas. Rev Port Ciênc Vet 100, 125-139.

Cal-Pereyra L, Benech A, González-Montaña JR, Acosta-Dibarrat J, Da Silva S, et al. 2015. Changes in the metabolic profile of pregnant ewes to an acute feed restriction in late gestation. New Zeal Vet $J$ 63, 141-146.

Carvalho PCF, Batello C. 2009. Access to land, livestock production and ecosystem conservation in the Brazilian Campos Biome: the natural grasslands dilemma. Livest Sci 120, 158-162.

Chilliard Y. 1999. Metabolic adaptations and nutrient partitioning in the lactating animal. In: Martinet J, Houdebine LM, Head HH (eds). Biology of Lactation. INRA, Paris, France, Pp 503-552.

Chilliard Y, Ferlay A, Faulconnier Y, Bonnet M, Rouel J, et al. 2000. Adipose tissue metabolism and its role in adaptations to undernutrition in ruminants. Proc Nutr Soc 59, 127-134.

Contreras PA. 2000. Indicadores do mecanismo proteico utilizados nos perfis metabólicos do rebanho. In: Gonzáles FHD, Barcellos JO, Patinõ HO, Ribeiro LA (eds). Perfil metabólico em ruminantes: Seu uso em nutrição e doenças nutricionais. Gráfica UFRGS, Porto Alegre, Brazil, Pp 9-23.

Durak MH, Altiner A. 2006. Effect of energy deficiency during late pregnancy in Chios Ewes on free fatty acids, $\beta$-hydroxybutyrate and urea metabolites. Turk J Vet Anim Sci 30, 497-502.

El-khodery S, EL-boshy M, Gaafar K, Elmashad A. 2008. Hypocalcemia in Ossimi sheep associated with feeding on beet tops (Beta vulgaris). Turk J Vet Anim Sci 32, 199-205.

El-sherif MMA, Assad F. 2001. Changes in some blood constituents of Barki ewes during pregnancy and lactation under semi arid conditions. Small Ruminant Res 40, 269-277.

Firat A, Ozpinar A. 2002. Metabolic profile of pre-pregnancy, pregnancy and early lactation in multiple lambing Sakiz ewes 1 . Changes in plasma glucose, 3-hydroxybutyrate and cortisol levels. Ann Nutr Metab 46, 57-61.

Fowden AL. 1997.Comparative aspects of fetal carbohydrate metabolism. Equine Vet J 24, 19-25.

Goff JP. 2006. Macromineral physiology and application to the feeding of the dairy cow for prevention of milk fever and other periparturient mineral disorders. Anim Feed Sci Tech 126, 237-257.

Harmeyer J, Schlumbohm C. 2006. Pregnancy impairs ketone body disposal in late gestating ewes: implications for onset of pregnancy toxemia. Res Vet Sci 81, 254-264.

Henze P, Bickhardt K, Fuhrmann H. 1994. The contributions of the hormones insulin, cortisol, somatotropin and total estrogen to the pathogenesis of sheep ketosis. Dtsch tierarztl wochenschr 10, 161-165.

Henze P, Bickhardt K, Fuhrmann H, Sallmann HP. 1998. Spontaneous pregnancy toxaemia (ketosis) in sheep and the role of insulin. $J$ Vet Med Series A 45, 255-266.

Herdt TH. 2000. Ruminant adaptation to negative energy balance. Influences on the etiology of ketosis and fatty liver. Vet Clin North Am Food Anim Pract 16, 215-230.

Ingvartsen KL, Andersen JB. 2000. Integration of metabolism and intake regulation: a review focusing on periparturient animals. J Dairy Sci 83, 1573-1597.

Jørgensen RJ. 1999. Induced hypocalcemia by $\mathrm{Na}_{2}$ EDTA infusion. A review. J Vet Med 46, 389-407.

Lee SH, Engle TE, Hossner KL. 2002. Effects of dietary copper on the expression of lipogenic genes and metabolic hormones in steers. $J$ Anim Sci 80, 1999-2005. 
Loor JJ, Dann HM, Guretzky NAJ. 2006. Plane of nutrition prepartum alters hepatic gene expression and function in dairy cows as assessed by longitudinal transcript and metabolic profiling. Physiol Genomic 27, 29-41.

Mavrogianni VS, Brozos C. 2008. Reflections on the causes and the diagnosis of peri-parturient losses of ewes. Small Ruminant Res 76, 77-82.

Oetzel GR. 2004. Monitoring and testing dairy herds for metabolic disease. Vet Clin North Am 20, 651-674.

Ribeiro LAO, Mattos RC, González FHD, et al. 2004. Perfil metabólico de ovelhas Border Leicester x Texel durante a gestacão e a lactação. Rev Port Ciênc Pet 99, 155-159.

Roubies N, Panousis N, Fytianou A, et al. 2006. Effects of age and reproductive stage on certain serum biochemical parameters of chios sheep under greek rearing conditions. J Vet Med A 53, 277-281.
Russel AJF, Doney JM, Gunn RG. 1969. Subjective assessment of body fat in live sheep. J Agr Sci 72, 451-454.

Rutter GA, Tsuboi T, Ravier MA. 2006. $\mathrm{Ca}^{2+}$ microdomains and the control of insulin secretion. Cell Calcium 40, 539-551.

Schlumbohm C, Harmeyer J. 2003. Hypocalcemia reduces endogenous glucose production in hyperketonemic sheep. J Dairy Sci 86 , 1953-1962.

Smith MC, Sherman DM. 1994. Goat Medicine. $1^{\text {st }}$ ed. Lea and Febiger, Philadelphia, USA.

Twardock AR, Symonds HW, Sansom BF, Rowlands GJ. 1973. The effect of litter size upon foetal growth rate and the placental transfer of calcium and phosphorus in superovulated Scottish half-bred ewes. Br J Nutr 29, 437-447. 